\title{
Effect of Differently Matured Compost Produced from Willow (Salix viminalis L.) on Growth and Development of Lettuce (Lactuca sativa L.) $^{\dagger}$
}

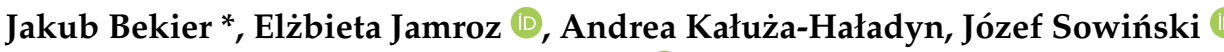 \\ and Katarzyna Adamczewska-Sowińska (D)
}

check for updates

Citation: Bekier, J.; Jamroz, E.;

Kałuża-Haładyn, A.; Sowiński, J.; Adamczewska-Sowińska, K. Effect of Differently Matured Compost Produced from Willow (Salix viminalis L.) on Growth and Development of Lettuce (Lactuca sativa L.). Biol. Life Sci. Forum 2021, 3, 7. https:// doi.org/10.3390/IECAG2021-10067

Academic Editor: Youssef Rouphael

Published: 17 May 2021

Publisher's Note: MDPI stays neutral with regard to jurisdictional claims in published maps and institutional affiliations.

Copyright: (c) 2021 by the authors. Licensee MDPI, Basel, Switzerland. This article is an open access article distributed under the terms and conditions of the Creative Commons Attribution (CC BY) license (https:// creativecommons.org/licenses/by/ $4.0 /)$.
Faculty of Life Sciences and Technology, Wroclaw University of Environmental and Life Sciences, pl. Gruwaldzki 24a, 50-363 Wrocław, Poland; elzbieta.jamroz@upwr.edu.pl (E.J.); andrea.kaluza12@gmail.com (A.K.-H.); jozef.sowinski@upwr.edu.pl (J.S.); katarzyna.adamczewska-sowinska@upwr.edu.pl (K.A.-S.)

* Correspondence: jakub.bekier@upwr.edu.pl; Tel.: +48-71-320-5639

+ Presented at the 1st International Electronic Conference on Agronomy, 3-17 May 2021; Available online: https://sciforum.net/conference/IECAG2021.

\begin{abstract}
Soil amendments from peats, brown coals and composts produced from segregated biodegradable waste or biomass from fallow land can increase soil fertility and improve soil productivity. The aim of the study was to determine the possibility of using willow (Salix viminalis L.) biomass composts as a substrate component in horticulture. The objects of the research were composts produced from willow chips (A), willow mixed with hay (B) and willow mixed with hay and mineral nitrogen (Nmin) fertilizer (C). Composting was carried out in a pile under aerobic conditions. In order to determine the properties and fertilizing value of the composts, basic chemical parameters were analyzed ( $\mathrm{pH}$; total contents of $\mathrm{C}, \mathrm{N}$ and $\mathrm{P}$ ), and a pot experiment was established to analyze germination and growth of lettuce (Lactuca sativa L.). Changes in $\mathrm{pH}$, total nitrogen content (TN), phosphorus (TP) and a decrease in TOC were observed in the investigated samples. The results of the experiment showed that the highest yield was obtained from the pots with the mixture of willow, hay and Nmin. Matured composts significantly stimulated the germination and growth of the test plants. It can be concluded that the addition of hay and Nmin significantly increased the fertilizing value of the investigated composts.
\end{abstract}

Keywords: composts; maturity; willow; fertilizing value

\section{Introduction}

In recent decades, a significant decrease in humus resources in terrestrial environments (especially cultivated areas), due to increased mineralization of organic matter, has been observed [1]. The consequences of these adverse changes are a rapid reduction in soil fertility and productivity and a catastrophic impact on crop production and the conservation values of terrestrial ecosystems [2]. This situation has given rise to concern among scientists. In order to reduce the negative effects of environmental changes, to improve soil quality and to increase soil organic matter (SOM) content, relevant guidelines, programmes and projects recommended by international organizations (FAO-WRB, IUSS, EGU-SSS, ISEB, etc.) have been developed [3,4]. The most likely solutions seem to be those suggesting the use of sustainable tillage and the introduction of organic or organic-mineral soil conditioners produced from exogenous organic matter (EOM). The use of alternative sources of EOM is also highly recommended: selected 'green waste,' biodegradable municipal waste or biomass from the cultivation of various plant species, with a particular focus on the concept of using biomass from the cultivation of energy willow as a substrate for compost production [5]. 
The aim of this study was to analyze selected chemical properties of composts produced from energy willow (Salix viminalis L.) as well as to determine their influence on germination and growth of lettuce (Lactuca sativa L.).

\section{Materials and Methods}

The objects of research were composts produced according to three variants: composts produced from willow chips; willow mixed with hay; and willow mixed with hay and mineral (ammonium nitrate $34 \% \mathrm{~N}$ ) nitrogen fertilizer (variants A, B and C, respectively). Samples for analysis were taken from piles at different maturity stage (after 1, 32, 71 and 167 days), then air-dried and ground and then ground mechanically to a diameter of 2.0 $\mathrm{mm}$. In the collected materials, the following determinations were performed: $\mathrm{pH}$ in 1 $\mathrm{mol} \mathrm{KCl} \cdot \mathrm{dm}^{-3}$, content of total organic carbon (TOC) and total nitrogen (TN) using Vario Macro Cube CN analyser (Elementar Analysensysteme $\mathrm{GmbH}$, Langenselbold, Germany) and content of total phosphorus (TP) by MP-AES 4200 analyzer (Agilent, Santa Clara, CA, USA). In order to determine fertilizer value and potential use of composts, two stages of pot experiment were established: the effect of composts at different maturity stages on germination (Stage 1) and initial growth (Stage 2) of lettuce (Lactuca sativa L.). A randomized complete block method was used with the following parameters: 20 seeds per pot in 3 replicates (Stage1) and 3 seedlings per pot in 3 replicates (Stage 2) for each variant, respectively. During the experiment, the influences of two factors were investigated: the type of composting variant and compost maturity stage. The obtained results were statistically processed with Statistica 13 software. Differences among objects were checked according to Tukey's test at a significance level of $<0.05$.

\section{Results and Discussion}

The results presented in this paper are based on mean values obtained during chemical analyses and resulting from the vegetation experiment.

\section{Changes in $\mathrm{pH}, \mathrm{TOC}, \mathrm{TN}$ and TP Contents}

Changes in $\mathrm{pH}$ during composting indicate the intensity of biochemical processes. Values of $\mathrm{pH}$ in the range 5.5 to 8.0 are considered the most optimal, while the final product should be neutral or slightly acidic [6,7]. The analysis of the obtained results (Figure 1, Table 1) indicates acidification that is too high relative to the tested composts. Regardless of the variants used, the lowest value of this parameter was found in the initial materials: $\mathrm{pH}_{\mathrm{KCl}}$ from 4.16 to 5.12 (variants $\mathrm{A}$ and $\mathrm{B}$, respectively). Additionally, statistical analysis (Table 1) showed significant differences between the tested samples.

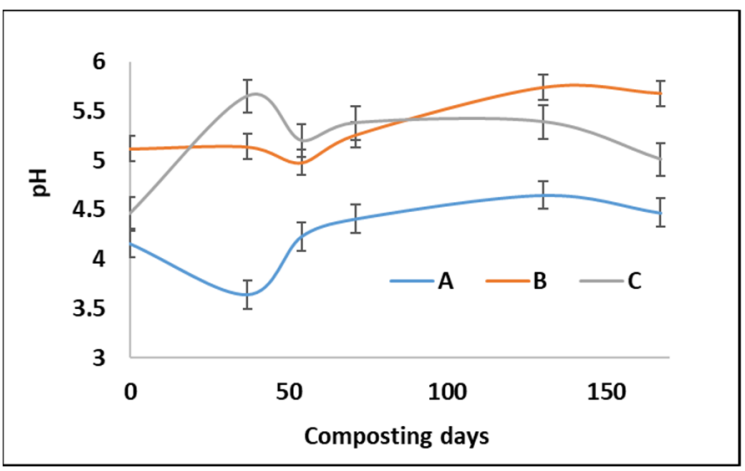

Figure 1. Changes in $\mathrm{pH}_{\mathrm{KCl}}$ during composting of willow chips. 
Table 1. Changes in basic chemical parameters of differently matured composts produced from willow.

\begin{tabular}{|c|c|c|c|c|c|c|c|c|}
\hline \multirow{2}{*}{ Variant } & \multirow[b]{2}{*}{1} & \multirow[b]{2}{*}{ St. Dev. } & \multicolumn{6}{|c|}{ Composting Days } \\
\hline & & & 32 & St. Dev. & 71 & St. Dev. & 167 & St. Dev. \\
\hline & & & \multicolumn{6}{|c|}{$\mathrm{pH}$} \\
\hline A & $4.16^{\mathrm{a}}$ & 0.07 & $3.64^{\mathrm{a}}$ & 0.12 & $4.41^{\mathrm{a}}$ & 0.13 & $4.47^{\mathrm{a}}$ & 0.13 \\
\hline $\mathrm{B}$ & $5.12^{b}$ & 0.09 & $5.14^{\mathrm{a}}$ & 0.08 & $5.26^{\mathrm{b}}$ & 0.16 & $5.68^{b}$ & 0.17 \\
\hline \multirow[t]{2}{*}{$\mathrm{C}$} & $4.46^{\mathrm{c}}$ & 0.16 & $5.65^{\mathrm{ba}}$ & 0.17 & $5.38^{b}$ & 0.16 & $5.01^{\mathrm{c}}$ & 0.15 \\
\hline & & & \multicolumn{6}{|c|}{ TOC $\mathrm{g} \mathrm{kg}^{-1}$} \\
\hline $\mathrm{A}$ & $478.9^{\mathrm{a}}$ & 14.37 & $469.6^{a}$ & 14.09 & $455.6^{\mathrm{a}}$ & 13.67 & $458.4^{\mathrm{a}}$ & 13.75 \\
\hline $\mathrm{B}$ & $431.4^{b}$ & 12.94 & $409.1^{\mathrm{ab}}$ & 12.27 & $425.4^{b}$ & 11.25 & $374.9^{b}$ & 11.25 \\
\hline \multirow[t]{2}{*}{$\mathrm{C}$} & $404.1^{\mathrm{C}}$ & 12.12 & $403.3^{b}$ & 12.10 & $399.1^{b}$ & 11.24 & $374.8^{c}$ & 11.24 \\
\hline & & & \multicolumn{6}{|c|}{$\mathrm{TN} \mathrm{g} \mathrm{kg}^{-1}$} \\
\hline $\mathrm{A}$ & $4.30^{\mathrm{a}}$ & 0.12 & $4.54^{\mathrm{a}}$ & 0.14 & $5.59^{\mathrm{a}}$ & 0.17 & $6.71^{\mathrm{a}}$ & 0.20 \\
\hline $\mathrm{B}$ & $6.90^{b}$ & 0.20 & $8.343^{b}$ & 0.24 & $9.57^{b}$ & 0.28 & $13.39^{b}$ & 0.39 \\
\hline \multirow[t]{2}{*}{$\mathrm{C}$} & $9.78^{\mathrm{c}}$ & 0.29 & $27.70^{\mathrm{c}}$ & 0.81 & $36.66^{c}$ & 1.10 & $50.06^{c}$ & 1.46 \\
\hline & & & \multicolumn{6}{|c|}{$\mathrm{TP} \mathrm{g} \mathrm{kg}^{-1}$} \\
\hline A & $1.36^{\mathrm{a}}$ & 0.05 & $1.26^{\mathrm{a}}$ & 0.04 & $1.33^{\mathrm{a}}$ & 0.05 & $1.39^{\mathrm{a}}$ & 0.05 \\
\hline B & $1.12^{b}$ & 0.04 & $1.12^{b}$ & 0.04 & $1.55^{b}$ & 0.05 & $1.77^{\mathrm{b}}$ & 0.06 \\
\hline $\mathrm{C}$ & $0.92^{c}$ & 0.04 & $1.60^{\mathrm{c}}$ & 0.06 & $1.36^{\mathrm{a}}$ & 0.05 & $1.03^{c}$ & 0.04 \\
\hline
\end{tabular}

Means followed by the same letter are not significantly different at $p<0.05$ (ANOVA).

However, it should be noted that the dynamics of these changes differed between the composting variants. They result mainly from the composition of the composted biomass and the intensity and direction of organic and mineral component transformations [8,9]. These phenomena are determined by the biodegradability of the substrates used and the conditions of the composting process [10].

In all investigated samples, a decreasing trend in TOC content (Figure 2a. Table 1) was observed. The dynamics of these changes showed statistically significant differences between the variants used in the experiment. In the initial phase of composting, TOC ranged from 478.9 to $404.1 \mathrm{~g} \mathrm{~kg}^{-1}$ (variants $\mathrm{A}$ and $\mathrm{C}$, respectively), while in mature materials TOC ranged from 375.0 to $458.4 \mathrm{~g} \mathrm{~kg}^{-1}$ (variants B, C and A, respectively).

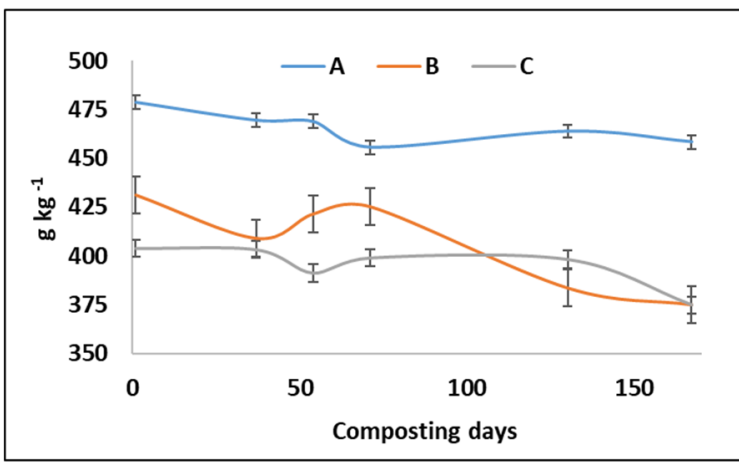

(a)

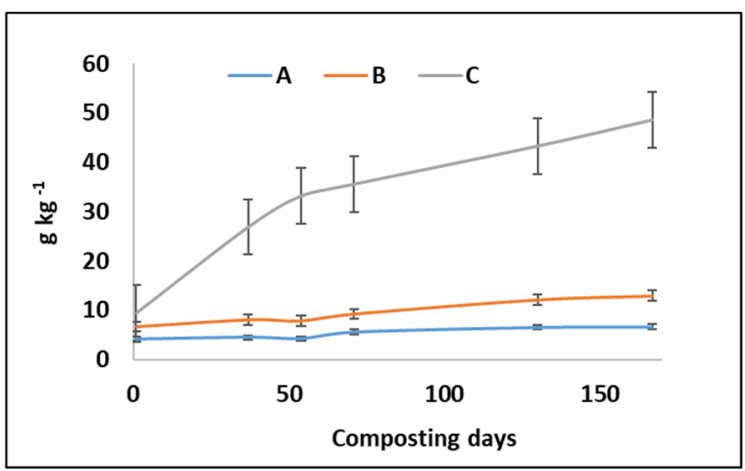

(b)

Figure 2. Changes in (a) TOC and (b) TN during composting of willow chips $\left(\mathrm{g} \mathrm{kg}^{-1}\right)$.

The most intensive processes of TOC transformations were observed in variant $B$ enriched with hay. Analysis of TN contents (Figure 2b, Table 1) showed a significant increasing trend in all tested composts, especially in variants enriched with hay and nitrogen fertilizer. The highest quantitative changes of TN from $9.78 \mathrm{~g} \mathrm{~kg}^{-1}$ in the initial material to $50.06 \mathrm{~g} \mathrm{~kg}^{-1}$ in the final product were observed for variant $\mathrm{C}$. In the studied composts (Figure 3, Table 1), the TP contents ranged from 0.92 to $1.36 \mathrm{~g} \mathrm{~kg}^{-1}$ in the initial materials (variants $\mathrm{C}$ and $\mathrm{A}$ ) and $1.03-1.77 \mathrm{~g} \mathrm{~kg}^{-1}$ in the final products (variants $\mathrm{C}$ and $\mathrm{B}$, respectively). 


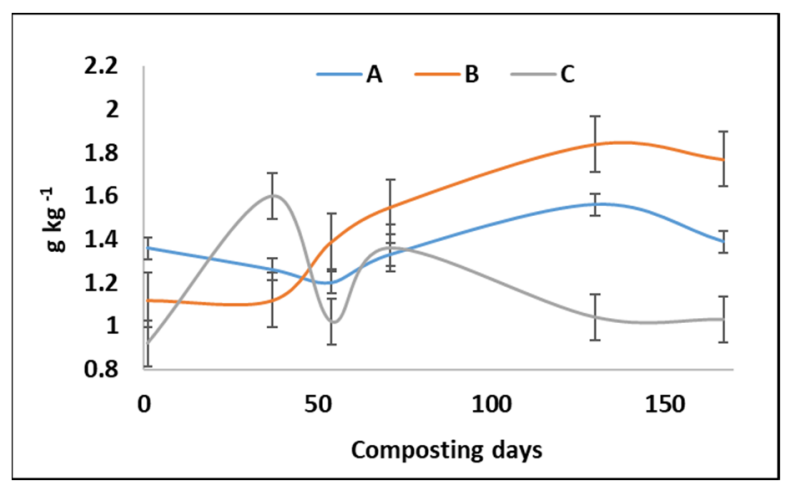

Figure 3. Changes in total phosphorus content $\left(\mathrm{g} \mathrm{kg}^{-1}\right)$ during composting.

Moreover, the dynamics of TP content changes were significantly different depending on the maturity of the compost and the composition of the composted mass.

The results of the first stage of the pot experiment (Table 2) indicated differences in the influence of the investigated composts on the germination of lettuce.

Table 2. Number of lettuce seedlings (Lactuca sativa L.) after 20 days of incubation (number per pot, mean values).

\begin{tabular}{|c|c|c|c|c|}
\hline \multirow{2}{*}{ Variant } & \multicolumn{4}{|c|}{ Composting Days } \\
\hline & 1 & 32 & 71 & 167 \\
\hline A & 10 & 9 & 10 & 12 \\
\hline B & 14 & 15 & 15 & 13 \\
\hline $\mathrm{C}$ & 0 & 9 & 12 & 14 \\
\hline Control & \multicolumn{4}{|c|}{8} \\
\hline
\end{tabular}

- -significant at $p<0.05 ;$ LSD $=5.00$ (ANOVA).

Although the number of germinated seeds in control sample 8 was lower than in all the tested composts (9-15 (variants A, C and B, respectively)), the samples of variant $\mathrm{B}$ significantly stimulated germination regardless of composting time. Furthermore, the lack of statistical significance for variants A (all samples) and C (samples after 1, 32 and 71 days of composting) may indicate the effect of an inhibitory factor present in these composts [11].

The results obtained in the second stage of the pot experiment (Table 3) showed that lettuce yields obtained from variant $C$ samples after 1,71 and 167 days of composting (4.70, 10.37 and $5.55 \mathrm{~g} \mathrm{pot}^{-1}$, respectively) were significantly higher than the yield of the control: $2.17 \mathrm{~g}$ pot-1. Moreover, similarly to the germination experiment, samples of variant A did not significantly influence lettuce growth and yield.

Table 3. Lettuce yield obtained from seedlings after 20 days of experiment (grams per pot, mean values).

\begin{tabular}{ccccc}
\hline \multirow{2}{*}{ Variant } & \multicolumn{5}{c}{ Composting Days } \\
\cline { 2 - 5 } & $\mathbf{1}$ & $\mathbf{3 2}$ & $\mathbf{7 1}$ & $\mathbf{1 6 7}$ \\
\hline $\mathrm{A}$ & 1.22 & 1.83 & 1.13 & 1.35 \\
$\mathrm{~B}$ & 0.86 & 1.98 & 2.09 & 2.15 \\
$\mathrm{C}$ & 4.78 & 1.97 & 10.37 & 5.55 \\
Control & & & 2.17 & \\
\hline - - & &
\end{tabular}

The results obtained from the chemical analyses and vegetation experiments indicate the potential usefulness of willow composts as an alternative fertilizer product. Thus, 
further research should be conducted for optimizing the composition of willow compost by using mineral and organic additives. It would also be useful to develop the most practical method for stimulating the composting process using technical and microbiological methods.

\section{Patents}

Some of the results presented in this article were used in a patent filed on 28 June 2020 at the Polish Patent Office No. P.435103. A legal procedure is currently underway.

\section{Conclusions}

Based on the results of the study, the following conclusions can be drawn: (1) Willow chips can be a substrate for the production of alternative fertilizer substances; however, they require appropriate organic and mineral additives and optimized composting conditions. (2) Despite applied organic and mineral additives, the tested composts were characterized by a relatively low fertilizer value. (3) The results of vegetation experiments showed that, regardless of the maturity stage, composts made of willow chips without additives (variant A) had an inhibitory effect on germination, growth and yield of lettuce. (4) The addition of hay and Nmin to willow chips significantly increased the properties of the investigated products, especially in mature compost. (5) The study demonstrated the utility of using both chemical test results and vegetation experiments to verify compost quality.

Supplementary Materials: The following are available online at https:/ / www.mdpi.com/article/10 .3390/IECAG2021-10067/s1.

Author Contributions: Conceptualization, J.B., E.J. and J.S.; methodology, J.B., A.K.-H. and E.J.; validation, E.J., J.S. and K.A.-S.; formal analysis, J.B. and E.J.; investigation, J.B., A.K.-H. and E.J.; resources, J.B., E.J. and J.S.; data curation, E.J. and J.B.; writing—original draft preparation, J.B.; writing—review and editing, J.B., E.J. and K.A.-S.; visualization, J.B. and E.J.; supervision, E.J. and J.S.; project administration, E.J. and J.B. All authors have read and agreed to the published version of the manuscript.

Funding: This research received no external funding.

Institutional Review Board Statement: Not applicable.

Informed Consent Statement: Not applicable.

Data Availability Statement: The data presented in this study are available on request from the corresponding author. The data are not publicly available until the invention patent (registration No. P.435103) is officially grant-ed.

Conflicts of Interest: The authors declare no conflict of interest.

\section{References}

1. Weber Jerzy, W.J.; Kocowicz Andrzej, K.A.; Bekier Jakub, B.J.; Jamroz Elżbieta, J.E.; Tyszka Rafał, T.R.; Dębicka Magdalena, D.M.; Parylak Danuta, P.D.; Kordas Leszek, L.K. The effect of a sandy soil amendment with municipal solid waste (MSW) compost on nitrogen uptake efficiency by plants. Eur. J. Agron. 2014, 54, 54-60. [CrossRef]

2. Lazcano Cristina, L.C.; Arnold, J.A.J.; Tato Anxo, T.A.; Zaller Johan, G.Z.J.G.; Dominguez Jorge, D.J. Compost and vermicompost as nursery pot components: Effects on tomato plant growth and morphology. Span. J. Agric. Res. 2009, 7, 944-951. [CrossRef]

3. Blum, W.E.H. (Ed.) Bulletin of the International Union of Soil Sciences; IUSS: Vienna, Austria, 2002; No 102; pp. 22-23.

4. Weber Jerzy, W.J.; Karczewska Anna, K.A.; Drozd Jerzy, D.J.; Licznar Michał, L.M.; Licznar Stanisława, E.L.S.E.; Jamroz Elżbieta, J.E.; Kocowicz Andrzej, K.A. Agricultural and ecological aspects of a sandy soil as affected by the application of municipal solid waste composts. Soil Biol. Biochem. 2007, 39, 1294-1302. [CrossRef]

5. Kaluza-Haladyn Andrea, K.-H.A.; Jamroz Elzbieta, J.E.; Bekier Jakub, B.J. Humic substances of differently matured composts produced from municipal solid wastes and biomass of energetic plants. Soil Sci. Ann. 2019, 70, 292-297. [CrossRef]

6. Kaluza-Haladyn Andrea, K.-H.A.; Jamroz Elzbieta, J.E.; Bekier Jakub, B.J. The dynamics of some physical and physico-chemical properties during composting of municipal solid wastes and biomass of energetic plants. Soil Sci. Ann. 2018, 69, 155-159. [CrossRef]

7. de Nobili Maria, N.M.; Petussi Fulvia, P.F. Humification index as evaluation of the stabilization degree during compost. J. Ferment. Technol. 1988, 66, 557-583. 
8. Chefetz Benny, C.B.; Hatcher Patrick, G.H.P.G.; Hadar Yitzhak, H.Y.; Chen Yona, C.Y. Chemical and biological characterization of organic matter during composting of municipal solid waste. J. Environ. Qual. 1996, 25, 776-785. [CrossRef]

9. Jamroz, E.J.E.; Bekier Jakub, B.J.; Medynska-Juraszek Agnieszka, M.-J.A.; Kaluza-Haladyn Andrea, K.-H.A.; Cwielag-Piaseck Irmina, C.-P.I.; Bednik Magdalena, B.M. The contribution of water extractable forms of plant nutrients to evaluate MSW compost maturity: A case study. Sci. Rep. 2020, 10, 12842. [CrossRef]

10. Chefetz Benny, C.B.; Hadar Yitzhak, H.Y.; Chen Yona, C.Y. Dissolved organic carbon fractions formed during composting of municipal solid waste: Properties and significance. Acta Hydrochim. Hydrobiol. 1998, 469, 111-119. [CrossRef]

11. Chanyasak Veerapan, C.V.; Katayama Arata, K.A.; Hirai Fukui Mitsuyo, H.F.M.; Mori Satoshi, M.S.; Kubota Hiroshi, K.H., II. Growth inhibitory factors and assesment of degree of maturity by org-C/org-N ratio of water extract. Soil Sci. Plant Nutr. 1983, 29, 215-219. 